\title{
Erectile Dysfunction Brought about by Love Towards Wife: A Case Report
}

\author{
Anna NG Hoi Nga* \\ Sex Therapist, Hong Kong Sexual Health Center, Hong Kong
}

Submission: May 22, 2017; Published: June 05, 2017

*Corresponding author: Anna NG Hoi Nga, Sex Therapist, Hong Kong Sexual Health Center, Neo Health Group, Hong Kong, Tel: 36536760; Email: hnng@cihe.edu.hk

\section{Introduction}

The brain of human being is often regarded as the most important sex organ. Not only does it constructs meanings for our sexuality but also regulates our sex hormonal secretion. When the status of hormonal secretion is imbalance, we may encounter sexual dysfunction which renders difficulty in reproduction. Medication may be helpful for some sexual dysfunction. However, when sexual dysfunction is caused by negative construction of the meaning of sexuality, treatment by medication may become ineffective and non-medical intervention can be more appropriate. This paper illustrates a case of erectile dysfunction which is caused by distorted attitudes towards sexuality. Nonmedical intervention is introduced and its effectiveness within two sessions was demonstrated.

\section{Case Illustration}

Ken (pseudo name) held a PhD degree and taught in a tertiary institute. He was 35 years old at the time of his first consultation in 2011. Ken had been in dating relationship with his current wife (pseudo name: Judy) for 10 years before their marriage. The couple planned to have a baby three years after their marriage. Unfortunately, Ken at this stage exhibited erectile dysfunction when having sex with Judy. Additionally, he felt reluctant to have sex with her. Over the three years of marriage, Ken has only tried two or three times intercourse with Judy. Judy thought that if they could not have a baby due to Ken's erectile dysfunction, she might file a divorce. She wrote a letter to Ken expressing her disappointment regarding his sexual performance and pushed him to seek help from a sex therapist.

In the first session, Ken reported that he had difficulty in erection when having sex with Judy and he had very low desire to have sex with her. His medical report revealed no physical basis of his sexual dysfunction. He masturbated on an average of twice a week. The presenting problem of Ken was that the more he loved Judy, the greater his difficulty in getting an erection. Ken said that in the first three years of dating relationship, he had sexual intercourse with Judy and had no erectile dysfunction.
However, when his love towards Judy got stronger day by day, and year by year, he found it difficult to have an erection. Furthermore, he started to experience low level of desire to have sex with Judy. He disclosed that after their marriage, the intensity of his love towards Judy increased enormously. He regarded Judy as a perfect woman and a perfect wife. He claimed that the only 'defect' he recently discovered about Judy was that she had been initiating sex lately. He said a perfect woman should not initiate sexual behavior. He felt very distressed when Judy proposed for a divorce from him. It saddened him when she proposed a divorce because of his erectile dysfunction. Nevertheless, he understood her disappointment as both of them wanted to have a baby'.

Ken's sexual history was investigated after exploring his presenting problems. He had no sexual abuse history. He shared that his sexual attitude was to a great extent affected by his peers in the secondary school. He used to watch pornography books and magazines with his male friends. When asked about how the meaning of sexuality was developed, he claimed that the meaning of sex was gradually constructed during the years while studying in the secondary school. To him, sex is dirty, immoral, and it is a way to manipulation woman. He expressed that the more he loved Judy, the more he felt reluctant to have sex with her because he did not want to carry out the dirty, immoral, and manipulative behavior with Judy whom he loved dearly. He said whenever he had a sexual urge, he masturbated and fantasized having sex with those 'dirty' and 'bad' women. It appeared that the strongly held misperceptions of sexuality were the major cause of Ken's erectile dysfunction.

During the assessment interview, Ken revealed that he has a lovely cat at home. In order to help Ken establish a connection between love and bodily intimacy, the therapist asked Ken to share his expression of intimacy and care towards his cat. He disclosed that he would touch the cat tenderly on its back when he wanted to be close to the cat. The interview revealed that in addition to the misperception of sexuality, Ken also believed that 
'Heavenly Principal' (Tian Li 天理) and 'Human Desire' (Ren Yu 天理) cannot co-exist. His ultimate purpose of life was to become a highly moral man by eliminating human desire (Ren Yu) so that he could get closer to the Heavenly Principal (Tian Li). The ABC model of Cognitive Behavioral Therapy [1] was then introduced to help Ken understand that the meaning he attached to sexuality was not necessarily true. The therapist also explained to him that it could be his distorted beliefs towards sexuality that was consequential to his dysfunctional sexual behavior.

The therapist took the petting of cat as an example and helped Ken to see that bodily intimacy with his wife could be a way to express his affection and love towards her. His eyes and month opened widely when such line of thinking was presented to him. He found the idea stimulating and thought-provoking. He exclaimed, "I have never thought of it this way! Connecting love and intimacy with sex is indeed a brand new idea for me! I may need some time to digest this new idea!"

At the end of the session, Ken was asked to carry out Stage I of the sensate focus exercise [2] with his wife at home. Steps in carrying out the exercise were explained to him in details. Sexual intercourse was prohibited during the exercise. He was asked to come back two weeks later. During the second session of consultation, Ken shared that he felt more relaxed while having body interaction with Judy. With the new idea introduced to him in the first session, he told the therapist that he was so relieved and had great confidence in overcoming his difficulty. He wanted to come back again to share with the therapist his progress. Stage II of sensate focus exercise was introduced in the second session. He was told to carry out the exercise with Judy in the coming two weeks. The traditional linear human sexual response cycle introduced by Masters and Johnson [3] was described to him, which was followed by an explanation of the circular human sexual response cycle constructed by Rosemary Basson [4]. These two models of human sexual response cycles were explained and compared to illustrate the connection of emotional intimacy with human sexual desire. The role of emotional intimacy in leading to satisfactory sexual relationship was also highlighted. Ken did not come back for the third session but informed the therapist through phone that he had been making very good progress in overcoming his difficulty of erectile dysfunction. Two years later, Ken's baby girl became a new member in our planet.

\section{Discussion and conclusion}

Erectile dysfunction is the second common male sexual dysfunction in Hong Kong [5]. There are many causes of the dysfunction, e.g., physiological defects, work stress, relationship problems, or even the status of unemployment [6]. The client of this case report is a typical case showing how sexual attitude can lead to sexual dysfunction. In fact, many male clients prefer masturbation to having sex with their wife. Very often, MadonnaWhore Complex would cause men's difficulty in translating emotional intimacy into body intimacy. Distorted sexual attitude is one of the many factors that lead to erectile dysfunction. Men might encounter sexual dysfunction in adulthood due to difficulty in resolving conflicting sexual scripts before and after marriage. When men think that a perfectly moral person should follow Heavenly Principal (Tian Li), they may have difficulty in bridging intimacy with sex. Ken, a highly educated gentleman, is unfortunately a 'victim' of our inadequate sex education. More importantly, we need to reshape the orientation of our sex health education. In addition to showing the danger of risky sexual behavior, the functional and positive perspective of sexuality should be promoted.

\section{References}

1. Corey G (2009) Theory and Counseling of Counseling and Psychotherapy. Thomson Brooks/Cole, USA.

2. Kleinplatz P (2001) New Directions in Sex Therapy: Innovations and Alternatives. Taylor \& Francis, UK.

3. Masters WH, Johnson VE (1970) Human sexual inadequacy. Little Brown \& Co, Boston, USA.

4. Basson R (2000) The female sexual response: a different model. J Sex Marital Ther 26(1): 51-65.

5. Ng AHN (2016) Sexual problem in Hong Kong Chinese community. Current Sexual Health Report 8(3): 151-157.

6. Zhang HP, Yip AWC, Fan S, Yip PSF (2013) Sexual dysfunction among Chinese married men aged 30-60 years: A population-based study in Hong Kong. Urology 81(2): 334-339.

\section{Your next submission with Juniper Publishers will reach you the below assets}

- Quality Editorial service

- Swift Peer Review

- Reprints availability

- E-prints Service

- Manuscript Podcast for convenient understanding

- Global attainment for your research

- Manuscript accessibility in different formats

( Pdf, E-pub, Full Text, Audio)

- Unceasing customer service

Track the below URL for one-step submission https://juniperpublishers.com/online-submission.php 